\title{
Mechanisms of $\mathrm{I}_{\mathrm{hERG}} / \mathrm{I}_{\mathrm{Kr}}$ Modulation by $\alpha \mathbf{1}$ - Adrenoceptors in HEK293 Cells and Cardiac Myocytes
}

\author{
Janire Urrutia ${ }^{a}$ Aintzane Alday ${ }^{a}$ Mónica Gallego ${ }^{a, b} \quad$ L. Layse Malagueta-Vieira, \\ Ivan Arael Aréchiga-Figueroac Oscar Casis ${ }^{a, b}$ José Antonio Sánchez-Chapulac \\ aDepartment of Physiology, Faculty of Pharmacy, University of the Basque Country UPV/EHU, Vitoria- \\ Gasteiz; 'Lascaray Research Centre, University of the Basque Country UPV/EHU, Vitoria-Gasteiz, Spain; \\ "Unidad de Investigación "Carlos Méndez" del Centro Universitario de Investigaciones Biomédicas, \\ Universidad de Colima, Colima, México
}

\section{Key Words}

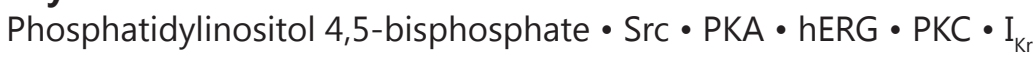

\begin{abstract}
Background: The rapid delayed rectifier $\mathrm{K}^{+}$current $\left(\mathrm{I}_{\mathrm{Kr}}\right)$, carried by the $\mathrm{hERG}$ protein, is one of the main repolarising currents in the human heart and a reduction of this current increases the risk of ventricular fibrillation. $\alpha 1$-adrenoceptors ( $\alpha 1-A R)$ activation reduces $I_{k r}$ but, despite the clear relationship between an increase in the sympathetic tone and arrhythmias, the mechanisms underlying the $\alpha 1-A R$ regulation of the hERG channel are controversial. Thus, we aimed to investigate the mechanisms by which $\alpha 1$-AR stimulation regulates $\mathrm{I}_{\mathrm{Kr}}$. Methods: $\alpha 1$ adrenoceptors, hERG channels, auxiliary subunits minK and MIRP1, the non PIP $_{2}$-interacting mutant D-hERG (with a deletion of the 883-894 amino acids) in the C-terminal and the non PKC-phosphorylable mutant $\mathrm{N}$-terminal truncated-hERG (NTK-hERG) were transfected in HEK293 cells. Cell membranes were extracted by centrifugation and the different proteins were visualized by Western blot. Potassium currents were recorded by the patch-clamp technique. $\mathrm{I}_{\mathrm{Kr}}$ was recorded in isolated feline cardiac myocytes. Results: Activation of the $\alpha 1-$ AR reduces the amplitude of $I_{\text {hERG }}$ and $I_{\mathrm{Kr}}$ through a positive shift in the activation half voltage, which reduces the channel availability at physiological membrane potentials. The intracellular pathway connecting the $\alpha 1-A R$ to the hERG channel in HEK293 cells includes activation of the Gaq protein, PLC activation and PIP ${ }_{2}$ hydrolysis, activation of PKC and direct phosphorylation of the hERG channel N-terminal. The PKC-mediated $\mathrm{I}_{\mathrm{Kr}}$ channel phosphorylation and subsequent $\mathrm{I}_{\mathrm{Kr}}$ reduction after $\alpha 1$-AR stimulation was corroborated in feline cardiac myocytes. Conclusions: These findings clarify the link between sympathetic nervous system hyperactivity and $\mathrm{I}_{\mathrm{Kr}}$ reduction, one of the best characterized causes of torsades de pointes and ventricular fibrillation.
\end{abstract}




\section{Cellular Physiology Cell Physiol Biochem 2016;40:1261-1273

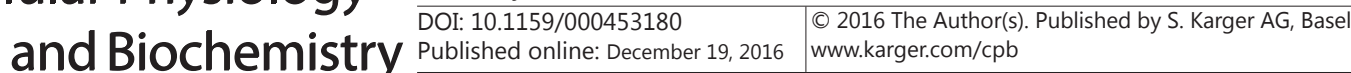 \\ Urrutia et al.: Cardiac $\mathrm{I}_{\mathrm{Kr}}$ and $\alpha 1-\mathrm{AR}$}

\section{Introduction}

The classical paradigm says that for an arrhythmia to be induced both a substrate and a trigger is needed. The human ether-a-go-go related gene (hERG) encodes the pore forming protein of the rapidly activated delayed rectifier $\mathrm{K}^{+}$current $\left(\mathrm{I}_{\mathrm{Kr}}\right)$, one of the most important currents that contributes to the repolarisation of the human heart. Reduction of this current either by a mutation in the gene or by a blockade of the channel by drugs produce congenital and acquired Long QT Syndrome (LQTS) respectively, creating a substrate that increases the risk of ventricular fibrillation [1]. The clinical observation showed that, in patients with LQTS, arrhythmias are typically triggered during physical or emotional stress, suggesting a link between sympathetic stimulation and arrhythmias. Sympathetic stimulation exerts different proarrhythmic effects, such as an increase of $\mathrm{I}_{\mathrm{f}}$ or L-type $\mathrm{Ca}^{2+}$ currents and a reduction of hERG potassium channel activity [2,3]. In fact, activation of both $\beta$ - and $\alpha$-adrenoceptors (-ARs) regulate $\mathrm{I}_{\mathrm{Kr}}$

$\beta$-AR stimulation has been proposed to regulate the Kv4.3 and hERG channels in cardiac myocytes [4] and heterologous systems inducing either an increase or a decrease of the hERG current. The proposed regulatory mechanisms of hERG included direct interaction of cAMP with the CNBD (cyclic nucleotide binding domain) of the channel, PKA-dependent phosphorylation and dynamic interaction with the 14-3-3 protein [5-8]. However, it was later demonstrated that cyclic nucleotides do not directly modulate hERG channels [9], and hERG-14-3-3 interaction has not been demonstrated in native cells. In fact, only an increase of $\mathrm{I}_{\mathrm{Kr}}$ via the activation of PKA has been demonstrated in native ventricular cells [10]. Regarding $\alpha 1$ adrenoceptors, although $\alpha 1$-AR activation also reduces native $\mathrm{I}_{\mathrm{Kr}}$ and $I_{\text {hERG }}$ in cardiac myocytes and in heterologous expression systems respectively, the specific mechanism remains elusive.

In 1999 it was reported for the first time a reduction in the $I_{\text {hERG }}$ upon $\alpha 1-A R$ activation, but the $G$ protein involved was not determined [11]. Later works proposed that phosphatidylinositol 4,5-bisphosphate ( $\mathrm{PIP}_{2}$ ) consumption by PLC mediated hydrolysis might cause such reduction [12], probably involving a direct interaction between PIP2 and the $\mathrm{C}$ terminus of the channel [13]. However, the $\mathrm{PIP}_{2}$-dependent regulation of hERG channel has been questioned since and is currently believed it is not essential for normal channel function $[14,15]$.

Simultaneously, other works proposed that the reduction of the $I_{\text {hERG }}$ upon $\alpha 1-A R$ stimulation was due to the phosphorylation of the hERG channel by PKA and PKC [16-18]. However, when mutation experiments in Xenopus oocytes showed that deletion of most of the consensus phosphorylation sites did not prevent the effect, authors suggested that hERG channels were modulated by PKA and PKC independently of direct phosphorylation [19]. It is important to note that not all the putative phosphorylation sites were mutated in that work and, therefore, the direct channel phosphorylation cannot be totally excluded.

In this work we aimed to investigate the molecular mechanism by which sympathetic activation of $\alpha 1$-AR regulates ventricular $\mathrm{I}_{\mathrm{Kr}}$. Thus, we analyzed the effect of $\alpha 1$-AR stimulation on hERG channel in Human Embryonic Kidney (HEK293) cells and on $\mathrm{I}_{\mathrm{Kr}}$ in feline cardiac myocytes.

\section{Materials and Methods}

\section{Cell culture and transfection}

Human Embryonic Kidney cells and a cell line stably expressing hERG channel [20] (HEK-hERG; Kindly provided by Dr. J. Hancox, University of Bristol, with the permission of Dr. C.T. January, University of Wisconsin) were cultured in DMEM (Dubelcco's modified Eagle's medium), supplemented with $10 \%$ of fetal bovine serum and $1 \%$ of penicillin-streptomycin-amphotericin cocktail. HEK-hERG grew in the presence of $50 \mu \mathrm{M}$ of geneticin. Cell cultures were maintained in $5 \% \mathrm{CO}_{2}$ at $37^{\circ} \mathrm{C} .4 \mu \mathrm{g}$ of D-hERG cDNA (kindly provided by Dr. T.V. McDonald, Albert Einstein College of Medicine, NY) or NTK-hERG cDNA (kindly provided by Dr. M.C. 


\section{Cellular Physiology Cell Physiol Biochem 2016;40:1261-1273 \begin{tabular}{l|l|l} 
and Biochemistry $10.1159 / 000453180$ & $\begin{array}{l}\text { DOI } 2016 \text { The Author(s). Published by S. Karger AG, Basel } \\
\text { Published online: December 19, } 2016\end{array}$ \\
www.karger.com/cpb
\end{tabular} \\ Urrutia et al.: Cardiac $\mathrm{I}_{\mathrm{kr}}$ and $\alpha 1-\mathrm{AR}$}

Sanguinetti, University of Utah) were transiently cotransfected with $1 \mu \mathrm{g}$ of $\alpha 1$-adrenoceptor cDNA (kindly provided by Dr. C. Hague, University of Washington) along with $0.2 \mu \mathrm{g}$ of GFP cDNA (kindly provided by Dr. M.T. Perez-Garcia, University of Valladolid) using Fugene 6 (Roche) following manufacturer instructions. Cells were used for electrophysiological studies and Western blot experiments $48-72 \mathrm{~h}$ after transfection.

\section{Western blot}

HEK293 cell membranes were isolated by centrifugation at 40000g, fractionated on $10 \%$ SDSpolyacrylamide gels and transferred to nitrocellulose membranes (Amersham Biosciences). Nitrocellulose membranes were blocked in TTBS solution (Tris-HCl $50 \mathrm{mM} \mathrm{pH} \mathrm{7.5,} \mathrm{NaCl} 150 \mathrm{mM}$, Tween-20 0.05\%) containing BSA $3 \%$. Blots were incubated with primary antibodies anti-hERG (1:200, Santa Cruz Biotechnology); anti- $\alpha 1-A R$ (1:400; Oncogene Research Products); anti-minK (1:100; Santa Cruz Biotechnology); and anti-MIRP1 (1:200; Abnova). Secondary antibodies were conjugated with Horseradish Peroxidase and blots were developed using enhanced chemiluminescence (West Pico, Thermo Scientific).

\section{Isolation of feline cardiomyocytes}

Animal studies have been approved by the Ethics Committee for the Humane Use of Laboratory Animals of the University of Colima (México) and the experiments were conducted following the ethical standards laid down in the Declaration of Helsinki and its later amendments.

Single right ventricular myocytes were obtained from adult cats as described previously [21]. Hearts were mounted on a Langendorff apparatus and perfused for $5 \mathrm{~min}$ with normal Tyrode's solution, and then switched to a nominally calcium-free solution for an additional $5 \mathrm{~min}$. Thereafter, the hearts were perfused for $30 \mathrm{~min}$ with a zero-calcium solution containing $1 \mathrm{mg} / \mathrm{ml}$ type I collagenase (Sigma-Aldrich, St. Louis, MO) and $0.05 \mathrm{mg} / \mathrm{ml}$ protease XIV (Sigma-Aldrich). The enzymes were washed out by perfusion with a highpotassium, low chloride saline (KB medium) for $5 \mathrm{~min}$ [22]. The free wall of the right ventricle was dissected away from the rest of the heart, placed in beakers, and cut into small pieces. Single cells were maintained in a high-potassium, low chloride solution at $4^{\circ} \mathrm{C}$ for $2 \mathrm{~h}$ before use in electrophysiological experiments.

Tyrode's solution had the following composition (in mM): $125 \mathrm{NaCl}, 24 \mathrm{NaHCO}_{3}, 0.42 \mathrm{NaH}_{2} \mathrm{PO}_{4}, 5.4 \mathrm{KCl}$, $1.8 \mathrm{CaCl}_{2}, 1.05 \mathrm{MgCl}_{2}, 11$ glucose, and 10 taurine. The solution was equilibrated with $95 \% \mathrm{O}_{2}$ and $5 \% \mathrm{CO}_{2}, \mathrm{pH}$ 7.4. Nominally calcium-free solution was prepared by omitting $\mathrm{CaCl}_{2}$ from the Tyrode's solution. The highpotassium, low-chloride $\mathrm{KB}$ medium had the following composition (in $\mathrm{mM}$ ): 80 potassium glutamate, 40 $\mathrm{KCl}, 20$ taurine, $3 \mathrm{KH}_{2} \mathrm{PO}_{4}, 10$ glucose, 10 HEPES, and 0.2 EGTA. pH 7.4 with KOH.

\section{Patch-clamp recordings}

Macroscopic currents were recorded at room temperature $\left(22^{\circ} \mathrm{C}\right)$ in the whole-cell configurations of the patch-clamp technique [23], using Axopatch-200B amplifiers (Molecular Devices). Borosilicate capillary glass were pulled obtaining a tip resistance of 1-3 $\mathrm{M} \Omega$ after filled with the internal solution. For HEK293 cells the internal solution was (in mM) $125 \mathrm{KCl}, 5 \mathrm{MgCl}_{2}, 5$ EGTA-K, 10 HEPES-K and $5 \mathrm{Na}$-ATP adjusted to $\mathrm{pH} 7.2$ with $\mathrm{KOH}$. For cardiac myocytes the internal solution was (in $\mathrm{mM}$ ): 90 potassium aspartate, $54 \mathrm{KCl}$, $10 \mathrm{KH}_{2} \mathrm{PO}_{4}, 5$ HEPES, $0.1 \mathrm{EGTA}$, pH 7.3 with $\mathrm{KOH}$.

Following the patch rupture, whole cell membrane capacitances were measured from integration of the capacitive transients elicited by voltage steps from -50 to $-60 \mathrm{mV}$, which did not activate any time dependent membrane current. Series resistances were compensated $80 \%$ in order to minimize voltage errors and were checked regularly throughout the experiment to ensure that there were no variations with time. The voltage-clamp experimental protocols were controlled with the "Clampex" program of the "pClamp" software (Molecular Devices). HEK293 cells were perfused with the external solution containing (in mM): $136 \mathrm{NaCl}, 4 \mathrm{KCl}, 1 \mathrm{MgCl} 2,10$ HEPES-Na, $1.8 \mathrm{CaCl}_{2}$ and 10 glucose, pH 7.4 with NaOH. For cardiac myocytes the bathing solution was (in $\mathrm{mM}$ ): $140 \mathrm{NaCl}, 5.4 \mathrm{KCl}, 0.1 \mathrm{CaCl}_{2}, 0.4 \mathrm{CoCl}_{2}, 1.0 \mathrm{MgCl}_{2}, 10 \mathrm{HEPES}$ and 11 glucose, $\mathrm{pH}$ adjusted to 7.4 with NaOH. HMR-1556 $1 \mu \mathrm{M}$ was added to block $\mathrm{I}_{\mathrm{Ks}}$. For HEK-hERG cells terfenadine $1 \mu \mathrm{M}$ was added at the end of the experiment and the remaining endogenous current was subtracted.

To elicit $\mathrm{I}_{\mathrm{hERG}}$ and $\mathrm{I}_{\mathrm{Kr}}$ we applied depolarizing pulses from -40 to +70 in $10 \mathrm{mV}$ increments for $2 \mathrm{~s}$ every 30 seconds from a holding potential of $-80 \mathrm{mV}$. These pulses were followed by a pulse at $-40 \mathrm{mV}$ for $5 \mathrm{~s}$ to measure tail current. I-V curves were obtained by measuring the current at the end of the test pulses, normalized to cell capacitance and expressed as $\mathrm{pA} / \mathrm{pF}$. The peak of the tail current was normalized to the 
maximum current and curves were fitted to Boltzmann relation $\mathrm{I}=1 /\left[1+\mathrm{e}\left(\mathrm{V}_{\mathrm{h}}-\mathrm{V}\right) / \mathrm{k}\right]$, were $\mathrm{I}$ is the amplitude of the tail current, $\mathrm{V}_{\mathrm{h}}$ is a half-maximal activation, $\mathrm{V}$ is the applied membrane voltage and $\mathrm{k}$ is the slope factor. Clampfit 10.2 software was used for the analysis of currents. The deactivation kinetics were calculated by fitting the decay of tail currents to a monoexponential function.

Drugs

Phenylephrine (PE), propranolol and neomycin were from Sigma-Aldrich. GP antagonist 2A (GPant2A); and bisindolylmaleimide 1 (BIS-1) were from Calbiochem. 1-phosphatidyl-1D-myo-inositol3,4-bisphosphate (diC8-PIP ${ }_{2}$ ) was from Echelon Biosciences. Anti-PIP 2 was from Santa Cruz Biotechnology. HMR-1556 was from Tocris.

\section{Statistical analysis}

Values are presented as mean \pm SEM. Student's t-test for paired data was used to compare the difference between two means. $\mathrm{p}<0.05$ was considered significant.

\section{Results}

Phenylephrine reduces $I_{\text {hERG }}$ in HEK293 cells

Cell lysates were immunoblotted to confirm the membrane expression of the $\alpha 1 \mathrm{~A}$ adrenergic receptor and the hERG channel. The adrenoceptor, as well as the two bands, mature glycosilated and inmature non-glycosilated, characteristic of the hERG channel proteins were detected only in transfected HEK-hERG cells (Fig. 1A).

Transfection was functional and cells responded to receptor stimulation with phenylephrine (PE). Thus, hERG channel current was recorded before and five minutes after $20 \mu \mathrm{M}$ PE administration and a reduction on both activated $\mathrm{I}_{\mathrm{hERG}}$ and tail current was observed (Fig. 1B). The current-voltage (I-V) relationship normalized to cell capacitance of the $\mathrm{I}_{\mathrm{hERG}}$ at

Fig. 1. $\alpha 1-A R$ stimulation reduces $\mathrm{I}_{\text {hERG }}$ and shifts the activation half voltage. A) Membrane expression of $\alpha 1 \mathrm{~A}$-ARs in untransfected and transfected HEK293 cells (left) and channel expression in HEK293 cells stably expressing hERG (right); duplicates are shown. B) Representative hERG current recordings in two HEK-hERG cells transfected with the $\alpha 1$ adrenoceptor before (Cont) and after administration of 2 or 20 $\mu \mathrm{M}$ phenylephrine (Phen). C) Current density-voltage curve and D) voltage dependence of activation in control and after $\alpha 1 \mathrm{~A}-\mathrm{AR}$ stimulation. E) Concentration-dependence of the effect of phenylephrine on the voltage dependence of $\mathrm{I}_{\text {hERG }}$ activation. The displacement of the
A

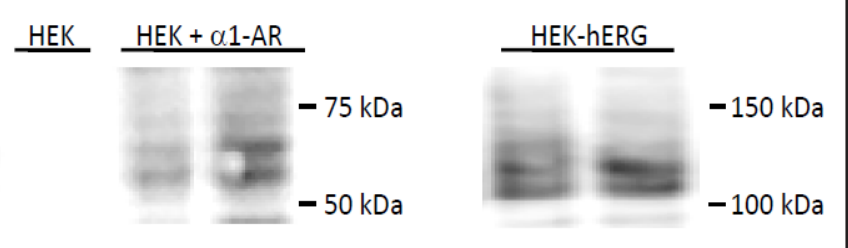

B
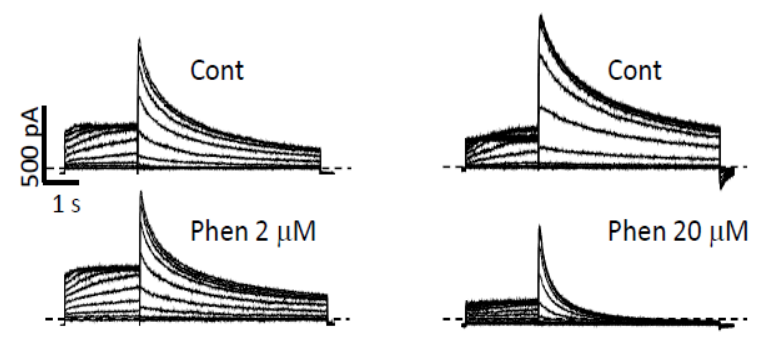

C
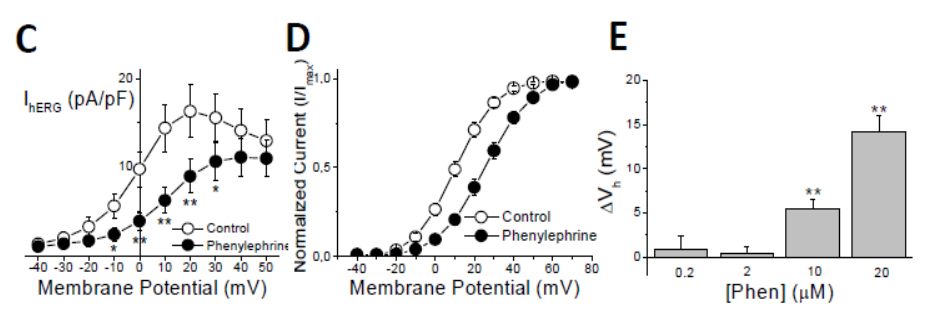
activation half voltage $\left(\Delta V_{h}\right)$ is plotted against phenylephrine concentration. Mean $\pm S E M ; n=7-37$ paired cells. ${ }^{*} \mathrm{p}<0.05 ;{ }^{* *} \mathrm{p}<0.01$. Dashed lines indicate the zero current level.

\section{KARGER}




\section{Cellular Physiology Cell Physiol Biochem 2016;40:1261-1273 \begin{tabular}{ll|l} 
DOI: 10.1159/000453180 & $\begin{array}{l}\text { O 2016 The Author(s). Published by S. Karger AG, Basel } \\
\text { www.karger.com/cpb }\end{array}$
\end{tabular} \\ Urrutia et al.: Cardiac $\mathrm{I}_{\mathrm{Kr}}$ and $\alpha 1-\mathrm{AR}$}

Fig. 2. minK and MIRP1 are not required for $\alpha 1$ AR induced regulation of $I_{\text {hERG. }}$ A) hERG Current recordings in a HEK-hERG cell not transfected with the $\alpha 1 \mathrm{~A}$-adrenoceptor before (Cont) and after adding $20 \mu \mathrm{M}$ phenylephrine (Phen). B) Western blot of minK and MIRP1 in untransfected ( $\varnothing$ ) and transfected HEK-hERG cells. C) Displacement of the $I_{h E R G}$ activation half voltage $\left(\Delta V_{h}\right)$ induced by $20 \mu \mathrm{M}$ phenylephrine in HEK-hERG cells not transfected with $\alpha 1$-AR (NO $\alpha 1-\mathrm{AR})$ and cotransfected with $\alpha 1-\mathrm{AR}$ plus either minK or MIRP1. Mean \pm SEM. $n=18,7,13$ paired cells. ${ }^{*} \mathrm{p}<0.01$. Dashed lines indicate the zero current level.

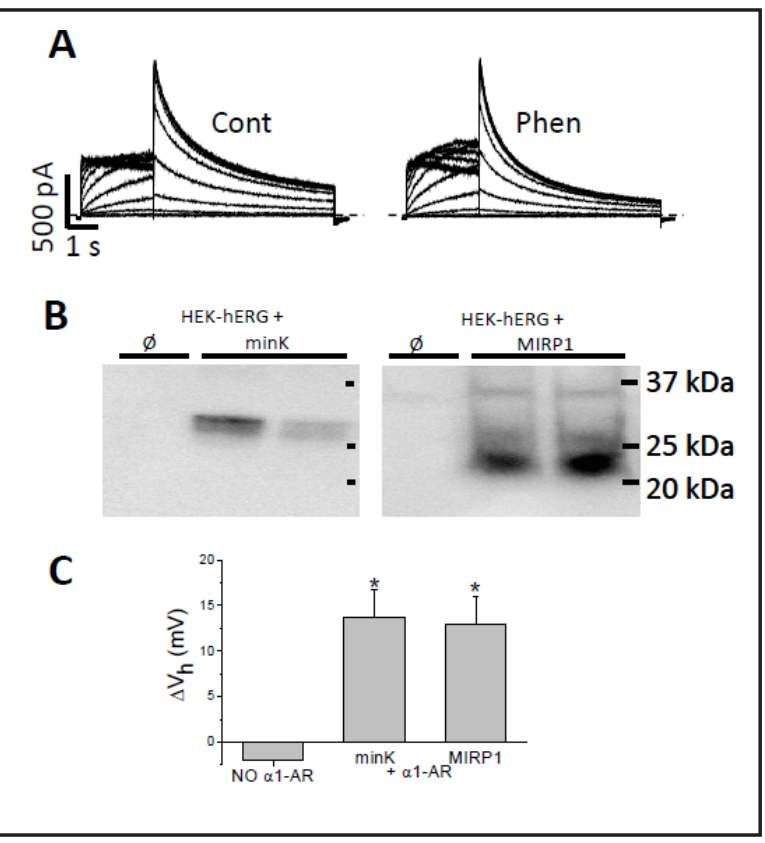

the end of the 2 seconds pulse in control and PE stimulation shows current inhibition in a wide voltage range: between -10 to $+30 \mathrm{mV}$. Because of the channel rectification properties, as the voltage increased the contribution of hERG channels to the total current become smaller and therefore the effect of PE was lower (Fig. 1C). Analysis of hERG tail currents showed that PE accelerates the current deactivation. When fitted to a monoexponential function, $\tau_{\text {deact }}$ was accelerated from $1331 \pm 74$ to $639 \pm 44 \mathrm{~ms}(\mathrm{n}=37$ paired cells, $\mathrm{p}<0.0001)$. The voltage dependence of hERG activation was calculated from plots of tail current amplitudes (normalized to the peak current) versus voltage. PE administration caused a $14 \mathrm{mV}$ positive shift in the activation half voltage $\left(\mathrm{V}_{\mathrm{h}}\right)$, from $10.9 \pm 1.9$ to $25.1 \pm 2.1 \mathrm{mV}(\mathrm{n}=37$ paired cells; $\mathrm{p}$ $<0.001$ ), and this effect was concentration-dependent, with an $\mathrm{EC}_{50}=12 \mu \mathrm{M}$ (Fig. 1D, E). PE concentrations higher than $40 \mu \mathrm{M}$ PE fully eliminated the $\mathrm{I}_{\mathrm{hERG}}$.

\section{$\alpha 1-A R$ stimulation shifts $h E R G$ channel activation $V_{h}$}

Since hERG channel has a great susceptibility to be blocked by many different drugs, we first tested whether the effects of PE on $\mathrm{I}_{\mathrm{hERG}}$ were due to $\alpha 1$-AR stimulation or to a blockade of the channel. Thus, when $20 \mu \mathrm{M}$ PE was added to hERG expressing HEK cells not transfected with the receptor, we still observed a faster tail current deactivation $11420 \pm 98$ vs $998 \pm 85 \mathrm{~ms} ; \mathrm{n}=18$ paired cells, $\mathrm{p}<0.0001$ ), suggesting a direct open channel blockade of the channel by PE. Conversely, the activation half voltage was not affected by phenylephrine in the absence of the receptor (Fig. 2). This result demonstrates that the positive shift in the hERG activation half voltage requires $\alpha 1-A R$ stimulation. In conclusion, the mechanism responsible for the $\mathrm{I}_{\mathrm{hERG}}$ reduction after the $\alpha 1$-AR activation is the positive displacement of the activation half voltage because, at a given membrane potential, the current amplitude is expected to be reduced.

\section{Neither minK nor MIRP1 modulate the $\alpha 1-A R$ regulation of $h E R G$ channels}

Although the real hERG partners in native systems is a matter of debate, in heterologous expression systems hERG channels can interact with the accessory proteins minK and MIRP1 [24]. We wondered whether these proteins could affect the $\alpha 1$-AR-induced $\mathrm{I}_{\mathrm{hERG}}$ reduction, so we transfected HEK-hERG cells with the receptor plus one of the accessory subunits and tested the effects of PE. Membrane expression of minK and MIRP1 was confirmed by Western blot (Fig. 2B).

Current recordings showed that $20 \mu \mathrm{M}$ PE shifted the $\mathrm{I}_{\mathrm{hERG}+\operatorname{minK}}$ activation $\mathrm{V}_{\mathrm{h}}$ to a similar extent than in the absence of the accessory protein (from $14 \pm 4.1$ to $27.7 \pm 3.1 \mathrm{mV}$; $\mathrm{n}=$ KARGER 


\section{Cellular Physiology Cell Physiol Biochem 2016;40:1261-1273 and Biochemistry Published online: \begin{tabular}{l|l} 
DOI: 10.1159/000453180 & (c) 2016 The Author(s). Published by S. Karger AG, Basel \\
www.karger.com/cpb
\end{tabular} \\ Urrutia et al.: Cardiac $\mathrm{I}_{\mathrm{K}_{\mathrm{r}}}$ and $\alpha 1-\mathrm{AR}$}

Fig. 3. $\alpha 1-A R$ induced $I_{\text {hERG }}$ regulation depends on PLC and PKC activation. A) hERG current recordings in a HEK-hERG cell transfected with the $\alpha 1 \mathrm{~A}$-adrenoceptor in control (Cont) and after administration of $20 \mu \mathrm{M}$ phenylephrine (Phen) in the presence of an anti-PIP ${ }_{2}$ antibody in the internal solution. B) Displacement of the $I_{\text {hERG }}$ activation half voltage $\left(\Delta V_{h}\right)$ caused by $\alpha 1-A R$ stimulation in cells with: the Gq protein blocker GPantagonist 2A $50 \mu \mathrm{M}$; the PLC inhibitors Neomycin $1 \mathrm{mM}$, anti-PIP antibody $80 \mathrm{nM}$ and diC8-PIP $210 \mu \mathrm{M}$; and the PKC blocker bisindolylmaleimide 1 (BIS-1) 10 $\mu$ M. Mean \pm SEM. $n=9,9,8,11,18$ paired cells. Dashed lines indicate the zero current level.

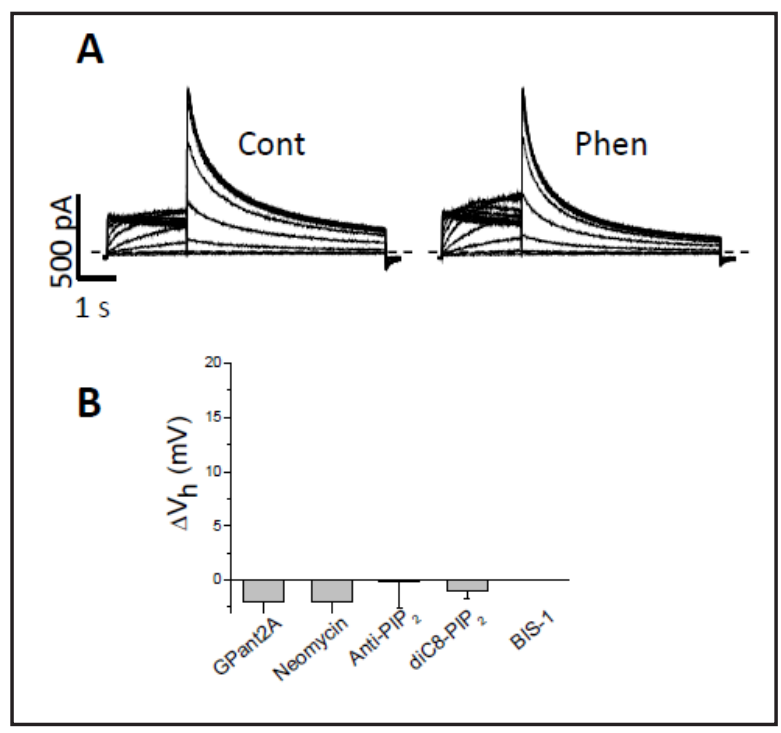

7 paired cells; $\mathrm{p}<0.01$ ). As expected, MIRP1 shifted $\mathrm{hERG}$ activation $\mathrm{V}_{\mathrm{h}}$ to more negative potentials. However, when PE was added to the cells the approximately $14 \mathrm{mV}$ shift in $\mathrm{I}_{\text {hERG }+\mathrm{MIRP} 1}$ activation half voltage was again observed (from $-1.2 \pm 3$ to $12.2 \pm 3.6 \mathrm{mV} ; \mathrm{n}=13$ paired cells; $\mathrm{p}<0.01$ ). As the effect of PE on the activation $\mathrm{V}_{\mathrm{h}}$ of $\mathrm{I}_{\mathrm{hERG}+\operatorname{minK}}, \mathrm{I}_{\mathrm{hERG}+\mathrm{MIRP} 1}$ and $\mathrm{I}_{\mathrm{hERG}}$ is basically identical, we can conclude that minK and MIRP1 do not alter the hERG channel response to the $\alpha 1$-ARs stimulation (Fig. 2C).

\section{Intracellular pathway mediating the $\alpha 1-A R$ modulation of $h E R G$}

The $\alpha 1$-adrenoceptor belongs to a G-protein coupled receptors family classically associated with Gaq dissociation, phospholipase C (PLC) activation, PIP ${ }_{2}$ hydrolysis and $\mathrm{PKC}$ activation. The involvement of the Gaq protein in the PE-induced $\mathrm{I}_{\mathrm{hERG}}$ reduction was confirmed with $50 \mu \mathrm{M}$ of the specific Gaq blocker GPant2A (RPKPQQDWFDWDWM). In the presence of this blocker PE did not shift the activation half voltage of $I_{\text {hERG }}$ (Fig. 3), suggesting that $\alpha \mathrm{q}$ is the relevant $\mathrm{G}$ protein in this pathway.

In the canonical pathway, Gaq protein-activated PLC hydrolyses $\mathrm{PIP}_{2}$ producing the PKC activators 1,2-diacylglycerol (DAG) and inositol-1,4,5,-trisphosphate ( $\mathrm{IP}_{3}{ }_{3}$ ). We blocked these steps with three chemical tools: neomycin and an anti-PIP ${ }_{2}$ antibody, which block the access of PLC to $\mathrm{PIP}_{2}$; and the non-hydrolysable $\mathrm{PIP}_{2}$ analogue diC8-PIP ${ }_{2}$, a putative competitive inhibitor of phospholipases [25-28]. The presence of each of the inhibitors prevented the PE-induced shift in $\mathrm{I}_{\mathrm{hERG}}$ activation half voltage (Fig. 3), indicating the involvement of PLC.

hERG channels are modulated by Ser/Thr kinases like PKA and PKC and by Tyrosine kinases such as Src $[19,29,30]$. Scansite database reveals 1 putative phosphorylation site for Src (Y1009) and 18 sites for PKA and/or PKC in the channel sequence. Our results showed that the effect of $\alpha 1-A R$ stimulation on $\mathrm{I}_{\mathrm{hERG}}$ does not depend on tyrosine kinases mediated phosphorylation. In the presence of the Tyr-kinase inhibitor genistein $50 \mu \mathrm{M}$ the activation $\mathrm{V}_{\mathrm{h}}$ moved from $10.3 \pm 3.4$ to $25.9 \pm 3 \mathrm{mV}$ after adding phenylephrine $(\mathrm{n}=9 ; \mathrm{p}<0.001)$. However, when PKC was inhibited by BIS-1 $(10 \mu \mathrm{M})$ PE was not able to shift the activation half voltage of $\mathrm{I}_{\text {hERG }}$ to more positive potentials (from $11.2 \pm 3.1$ to $11.3 \pm 3 \mathrm{mV}$; $\mathrm{n}=18$ paired cells, ns; Fig. 3 ). Thus, PKC has a key role in the regulation of the hERG channel after $\alpha 1$-AR stimulation.

To confirm that PIP $_{2}$ does not directly affect the channel modulation, HEK293 cells were cotransfected with the $\alpha 1$-AR plus the D-hERG mutant. This mutant has a deletion of the 883-894 amino acids in the C-terminal, the main site of interaction between $\mathrm{PIP}_{2}$ and hERG channels [13]. Perfusion of the cells with $20 \mu \mathrm{M}$ PE shifted the activation half voltage of $\mathrm{I}_{\mathrm{D}-\mathrm{hERG}}$ to more depolarized potentials (from $8.2 \pm 3$ to $20.1 \pm 3 \mathrm{mV}$; $n=11$ paired cells; $p<0.001$; Fig. 4 ), same as was observed with the wild type channel. On the contrary, addition of the nonhydrolysable analogue diC-8-PIP $2(10 \mu \mathrm{M})$ or the PKC blocker BIS-1 $(10 \mu \mathrm{M})$ prevented the 
Fig. 4. PIP2 interaction with hERG channel is not relevant for regulation by $\alpha 1-A R$. A) Expression of the presumably non PIP interacting mutant D-hERG in transfected HEK293 cells (duplicates are shown). B) $\mathrm{I}_{\mathrm{D} \text {-hERG }}$ recordings in a HEK cell coexpressing the D-hERG and the $\alpha 1-A R$, before (Cont) and after $20 \mu \mathrm{M}$ phenylephrine (Phen) administration. C) Displacement of the $I_{D \text {-hERG }}$ activation half voltage $\left(\Delta V_{h}\right)$ caused by PE in cells without $(\varnothing)$ and with diC8-PIP ${ }_{2}$ or bisindolylmaleimide 1 . Mean \pm SEM. $\mathrm{n}=11,7,8$ paired cells. ${ }^{*} \mathrm{p}<0.01$. Dashed lines indicate the zero current level.

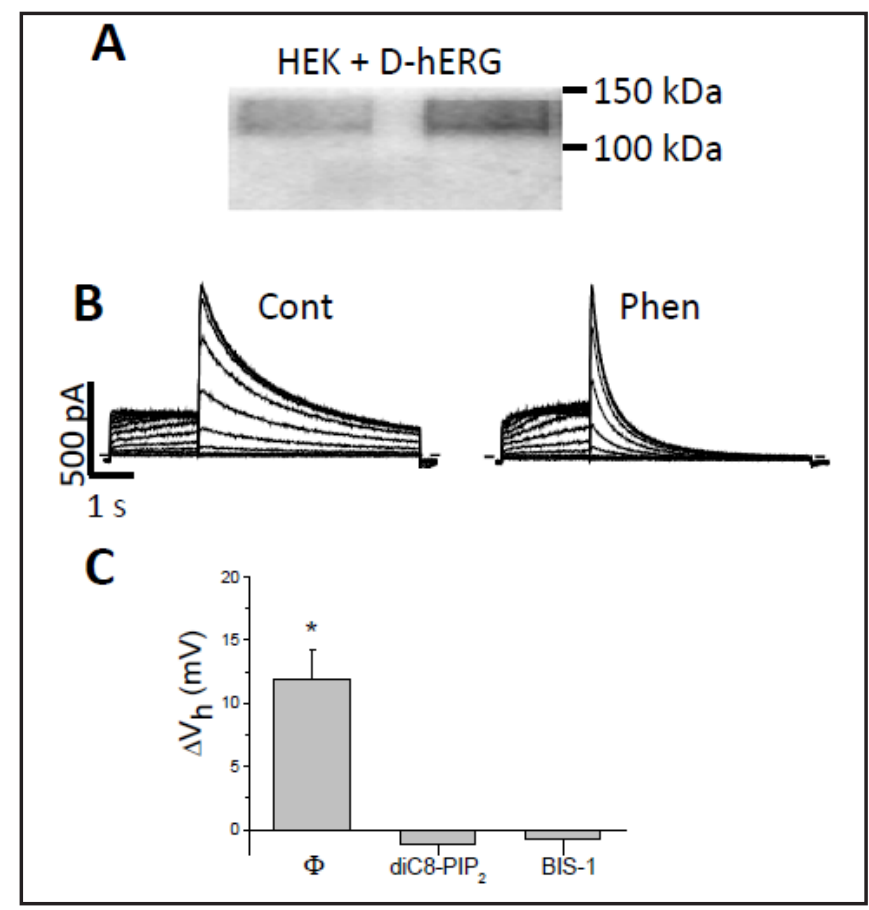

Fig. 5. hERG regulation by $\alpha 1$-ARs is dependent on PKC phosphorylation. A) Expression of the non PKC-phosphorylable mutant NTK-hERG in transfected HEK293 cells. B) $\mathrm{I}_{\text {NTK-hERG }}$ recordings in a HEK cell coexpressing the NTK-hERG and the $\alpha 1$ $\mathrm{AR}$, before (Cont) and after $20 \mu \mathrm{M}$ phenylephrine (Phen) administration. Since NTK-hERG tail deactivation kinetics are faster than WT, the inset shows an amplification of the tail currents. C) Displacement of the $\mathrm{I}_{\text {NTK-hERG }}$ activation half voltage $\left(\Delta \mathrm{V}_{\mathrm{h}}\right)$ caused by $20 \mu \mathrm{M}$ phenylephrine in cells without $(\varnothing)$ and with diC8-PIP 2 or bisindolylmaleimide 1 (BIS-1). Mean \pm SEM. $n=10,6,7$ paired cells. Dashed lines indicate the zero current level.

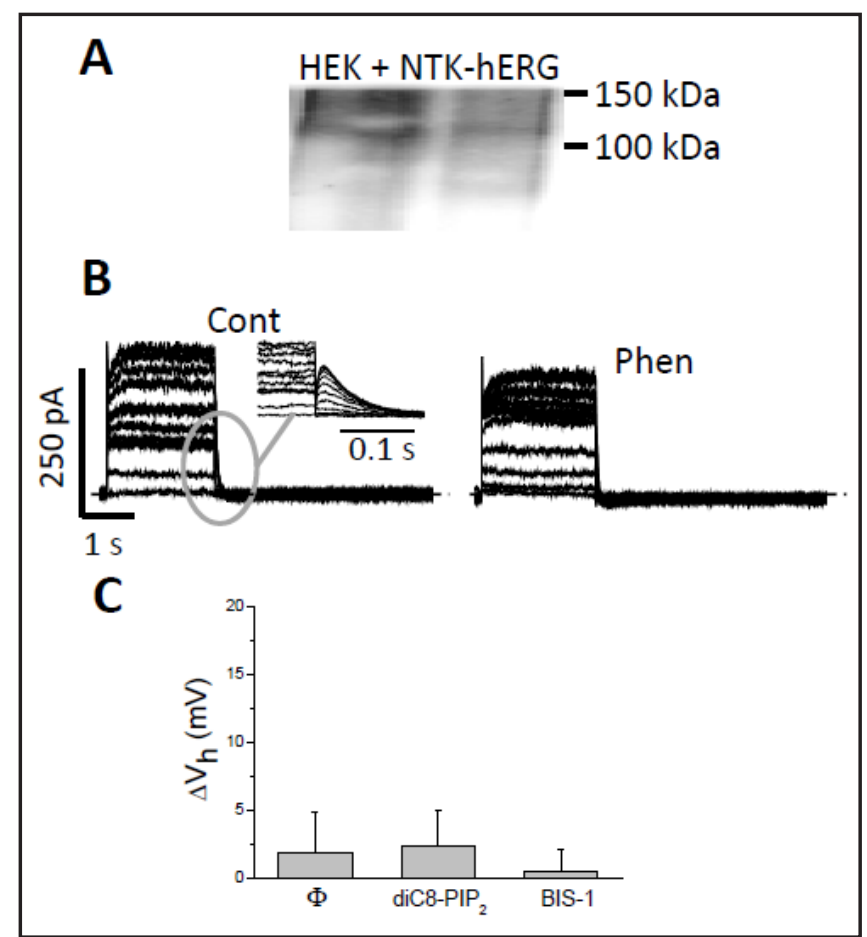

effect of PE on the deletion mutant, supporting the role of PKC-dependent phosphorylation of the channel (Fig. 4C).

In previous works the four PKA phosphorylation sites and 17 of the 18 consensus PKC phosphorylation sites in hERG were mutated to alanine and the channel modulation by the $\alpha 1$-AR was similar to WT channels $[19,31]$. However, the T74, located in the PerArnt-Sim (PAS) domain of the channel, cannot be deleted or mutated to alanine without the loss of function of the channel, showing that this is a key residue in the channel function. Interestingly, the T74 was demonstrated to be phosphorylated by PKC [32]. So we then 
A

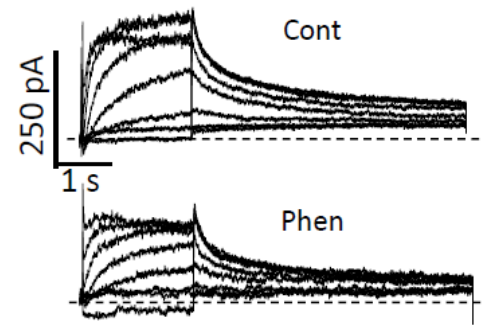

C

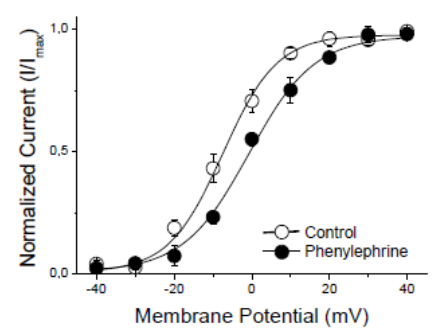

B
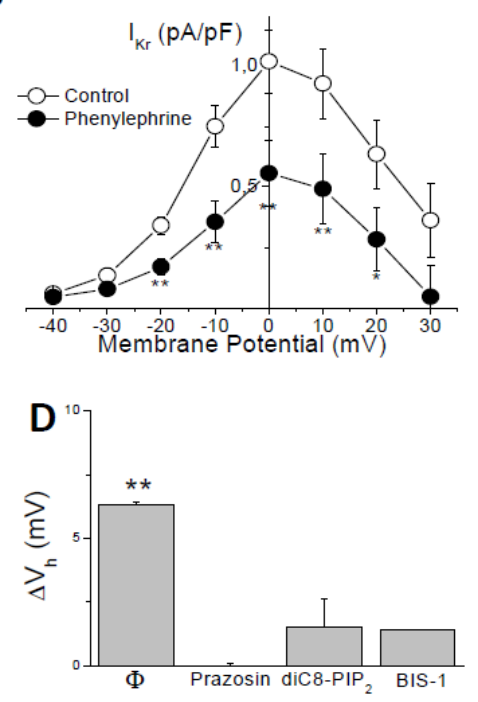

Fig. 6. $\alpha 1$-AR stimulation reduces $\mathrm{I}_{\mathrm{Kr}}$ by a PKC-phosphorylation mediated mechanism. A) $\mathrm{I}_{\mathrm{Kr}}$ recordings in a feline ventricular myocyte in control (Cont) and after application of $20 \mu \mathrm{M}$ phenylephrine (Phen). B) Current density-voltage curve and C) voltage dependence of activation before and after $\alpha 1$-AR stimulation. D) Displacement of the $I_{\mathrm{Kr}}$ activation half voltage $\left(\Delta \mathrm{V}_{\mathrm{h}}\right)$ induced by $\alpha 1$-AR stimulation in cells without $(\varnothing)$ and with prazosin $(1 \mu \mathrm{M})$, diC8-PIP ${ }_{2}$ or bisindolylmaleimide 1 (BIS-1). Mean \pm SEM. $n=10,5,6,5$ paired cells. * $\mathrm{p}<0.05{ }^{* *} \mathrm{p}<0.01$. Dashed lines indicate the zero current level.

cotransfected HEK293 cells with the $\alpha 1$-AR and the NTK-hERG channel, a mutant whose 2-354 amino acids containing the PAS domain and the T74 have been removed [33]. Although both activation and deactivation kinetics are faster in NTK-hERG than in WT hERG, the activation half voltage is similar and was not regulated by $P E$ (from $9.5 \pm 4.4$ to $11.3 \pm 3.4$ $\mathrm{mV} ; \mathrm{n}=10, \mathrm{~ns}$ ). The absence of effect of $\alpha 1$-AR stimulation on the NTK-hERG activation $\mathrm{V}_{\mathrm{h}}$ is again consistent with a major role of PKC in this regulation pathway. As expected, diC8-PIP2 or BIS-1 did not affect the $I_{\text {NTK-hERG }}$ activation $V_{h}$ after PE exposure (Fig. 5).

\section{$\alpha 1$-Adrenergic modulation of $I_{K r}$ in feline cardiac myocytes}

In order to test whether the results obtained in HEK-hERG cells could be extrapolated to native cardiac cells we used isolated feline ventricular cardiomyocytes. All the experiments with ventricular myocytes were performed in the presence of the $\beta$-blocker propranolol $100 \mathrm{nM}$ to avoid any potential effect of PE on $\beta$-ARs. As previously observed in transfected HEK293 cells, in feline native cardiomyocytes the stimulation of the $\alpha 1-\mathrm{AR}$ with PE reduced the $\mathrm{I}_{\mathrm{Kr}}$ activated current and shifted the activation half voltage to more depolarized potentials (from $-7.4 \pm 1.1$ to $-1.1 \pm 1.2 \mathrm{mV}, \mathrm{n}=10$ paired cells; $\mathrm{p}<0.01$ ). The specific $\alpha 1$-AR blocker prazosin $(1 \mu \mathrm{M})$ abolished the effect on $\mathrm{I}_{\mathrm{Kr}}$ indicating that is dependent on receptor activation (Fig. 6). The relevance of PKC in the intracellular pathway was tested using diC-8-PIP 2 and BIS-1 and, as expected, they abolished the PE effect on $\mathrm{I}_{\mathrm{Kr}}$. Therefore, PKC has a critical role on $\mathrm{I}_{\mathrm{Kr}}$ regulation upon $\alpha 1$-AR stimulation in ventricular myocytes.

\section{Discussion}

Mechanisms of $I_{h E R G}$ reduction upon $\alpha 1-A R$ stimulation

In this work, the activation of the $\alpha 1$-AR with phenylephrine reduces the $\mathrm{I}_{\mathrm{hERG}}$ amplitude as previously published $[12,13,19,31,34]$. The experiments performed in hERG-HEK cells not expressing $\alpha 1$-AR show that the shift in the activation $V_{h}$ to more positive potentials is 


\section{Cellular Physiology Cell Physiol Biochem 2016;40:1261-1273 \\ \begin{tabular}{l|l|l} 
and Biochemistry & Dublished online: December 19, 2016 & $\begin{array}{l}\text { (c) } 2016 \text { The Author(s). Published by S. Karger AG, Basel } \\
\text { www.karger.com/cpb }\end{array}$
\end{tabular} \\ Urrutia et al.: Cardiac $\mathrm{I}_{\mathrm{Kr}}$ and $\alpha 1-\mathrm{AR}$}

the cause of $\mathrm{I}_{\text {hERG }}$ reduction upon $\alpha 1 \mathrm{~A}$-AR stimulation, because there will be fewer available channels at any physiological membrane potential. The regulatory proteins minK and MIRP1 are not relevant for the $\alpha 1 \mathrm{~A}$-adrenergic regulation of $\mathrm{I}_{\mathrm{hERG}}$.

Jiang et al. found for the first time a reduction on $\mathrm{I}_{\mathrm{hERG}}$ amplitude by $\alpha 1 \mathrm{~A}-\mathrm{AR}$ stimulation; however the authors did not identify the $G$ protein involved [11]. Although this receptor can activate Gos protein and the cAMP/PKA pathway in cardiac myocytes [35], the most extensively documented biochemical responses to $\alpha 1$-AR stimulation in the heart is Gaq protein activation of phospholipase C-mediated hydrolysis of PIP2 that produces DAG and IP3 and leads to PKC activation by these second messengers [36-38]. Our results show that the regulation of hERG current is mediated by the canonical Gaq-PLC intracellular signalling pathway. It has been proposed that the effect of PLC activation on $\mathrm{I}_{\mathrm{hERG}}$ upon $\alpha 1-$ AR stimulation might be caused by PIP $_{2}$ depletion and loss of PIP P $_{2}$-hERG interaction $[12,13]$. However, other authors suggest that the channel modulation lies on DAG production and PKC-dependent phosphorylation [19, 31]. As will be discussed below, our experiments with deletion mutants support the latter.

\section{Implication of Protein Kinases}

The most common mechanism to regulate $\mathrm{K}^{+}$channels is reversible phosphorylation $[35,39]$. The Tyrosine kinase Src shifts the activation half voltage of both $I_{\mathrm{Kr}}$ and $\mathrm{I}_{\mathrm{hERG}}[30$, 40]. In our work, however, inhibition of Tyrosine kinases did not prevent the shift in the activation $V_{h}$ induced by $\alpha 1-A R$ stimulation, suggesting that they are not involved in this regulatory pathway.

Although several works propose a role for PKC in the modulation of hERG channels in response to Gaq protein coupled receptors [19, 29, 32, 41], one paper using the PKC inhibitor chelerythrine excluded PKC involvement in $\alpha 1$-AR modulation of hERG [12]. In that study cells were incubated extracellularly for one hour with a chelerythrine concentration barely above the $\mathrm{IC}_{50}$, so probably neither the incubation time nor the concentration used were enough to cause a significant blockade. We have administrated the PKC blocker bisindolylmaleimide- 1 in the intracellular solution to ensure inhibition of the kinase and then found that $\alpha 1-\mathrm{AR}$ stimulation does not shift the activation half voltage of $\mathrm{I}_{\mathrm{hERG}}$. Thus, PKC has a key role in the regulation of the hERG channel after $\alpha 1-A R$ stimulation.

Thomas et al. suggested that $\alpha 1-A R$ regulation of hERG channel was mediated by both PKA and PKC by a mechanism independent of direct channel phosphorylation [19], since PKA inhibition prevented the effect of $\alpha 1$-AR stimulation on $I_{\text {hERG }}$ but mutation of the four PKA phosphorylation sites did not. It is currently accepted that KT5720, the PKA blocker used, can also inhibit PKC at physiological ATP concentrations [42] and therefore involvement of PKA is not sustained. That work also ruled out the direct phosphorylation of the channel by PKC because mutation of 17 out of 18 phosphorylation sites to alanine did not prevent the $\alpha 1$-AR effect on hERG [19]. Authors could not exclude the T74 site, located in the PAS domain, as the target for PKC-dependent phosphorylation of hERG channel after $\alpha 1$-AR stimulation because mutation of that residue resulted in non-functional channels. In this sense, it is currently known that PKC modulates hERG channels $[29,31,41,43]$ precisely by direct phosphorylation of the T74 site [32]. Whereas point mutation or deletion of T74 causes channel loss of activity [19, 32], the NTK-hERG mutant lacks the full PAS domain and is functional enough to allow exploring the modulation by PKC $[32,33]$. In the present work, $\alpha 1$-ARs stimulation does not modulate $\mathrm{I}_{\text {NTK-hERG }}$ supporting a role for direct channel phosphorylation by PKC.

$\mathrm{PIP}_{2}$ regulates inward rectifier potassium channels [44-50], voltage dependent $\mathrm{Ca}^{2+}$ channels [reviewed in 51], cardiac $\mathrm{Na}^{+} / \mathrm{Ca}^{2+}$ exchanger [52], KCNQ1 [53] and a role for PIP ${ }_{2}$ in the regulation of $\mathrm{I}_{\mathrm{Kr}} / \mathrm{I}_{\mathrm{hERG}}$ by $\alpha 1$-AR has been proposed $[12,13,54]$.

Negative phosphate groups of the $\mathrm{PIP}_{2}$ head interact with positively charged amino acids of the channel proteins $[45,55]$ and the deletion or substitution of the 883-894 amino acids in the hERG channel C-terminal eliminates the apparent main interaction site between PIP and hERG [13]. We used the D-hERG mutant (deletion of C-terminal 883-894 amino acids) in 
order to test whether PIP $_{2}$ might be involved in the $\alpha 1-A R$ regulation of $\mathrm{I}_{\text {hERG. }}$. D-hERG mutant responds to $\alpha 1$-AR stimulation and behaves like the WT despite the lack of the apparent PIP interaction site. On the contrary, PKC inhibition fully abolishes $\alpha 1$-adrenergic modulation of D-hERG, which is again consistent with a relevant role of direct phosphorylation by PKC in this pathway.

\section{Limitations of the study}

Although PE induces a positive shift in the activation $V_{h}$ in both HEK cells and feline cardiac myocytes, the smaller effect of PE in feline myocytes can be explained by different factors such as a lower $\alpha 1$-AR expression. Feline myocytes are native cells, whereas in HEK cells the receptor was transfected and overexpressed. It might also be differences in efficiency of coupling between the components of the intracellular pathway (receptor-Gq proteins; Gq-PLC; PLC-PKC;...) or a different stoichiometry between PKC and ERG channels.

Feline $\mathrm{I}_{\mathrm{Kr}}$ is not identical to transfected $\mathrm{I}_{\mathrm{hERG}}$. In addition to the possible differences between feline and human ERG channel, it is well accepted that hERG channel resembles most but not all the characteristics of human $\mathrm{I}_{\mathrm{Kr}}$ and that accessory subunits would be required to create the chanelosome responsible for native $\mathrm{I}_{\mathrm{Kr}}$. However, we found that the main candidates, minK or MIRP1, do not modify the effect of Phenylephrine on hERG.

\section{Translational perspective}

Our results in native, feline, cardiomyocytes reproduce what was observed in transfected cells. Thus, $\alpha 1-\mathrm{AR}$ stimulation reduces the $\mathrm{I}_{\mathrm{Kr}}$ activated and tail currents by shifting the voltage-dependence of activation to more depolarized potentials in a mechanism that requires PLC and PKC activation and PKC-dependent channel phosphorylation.

One common trigger of arrhythmia in LQT2 patients seems to be emotional stress and high and unexpected noise [56]. Symptomatic patients that suffer lethal and no lethal cardiac events are related with an increase in the sympathetic tone [3,57-59], which means a clear relation between sympathetic nervous system and arrhythmias. In fact, auditory stimulusinduced arrhythmias are almost exclusively associated with mutations in KCNH2, the gene encoding hERG [2]. $\beta$-AR and $\alpha$-AR are activated by noradrenalin, but although $\beta$-ARs are saturated by moderate sympathetic activation, $\alpha 1$-ARs activate in situations of sympathetic hyperactivity such as emotional or physical stress. In this sense, an anti-arrhythmic effect of a1-AR blockade has been demonstrated in an animal model of LQT2 [60]. Here, we clarified the link between sympathetic nervous system hyperactivity and $\mathrm{I}_{\mathrm{Kr}}$ reduction, one of the best characterized causes of torsades de pointes and ventricular fibrillation.

\section{Acknowledgements}

This work was supported by Universidad del País Vasco UPV/EHU grants (PPM12/12 and PES12-33); Basque Government grant IT653-13 and MINECO (SAF2013-46708-R) to O.C.; and UPV/EHU grant (EHUA12/12) to M.G. The authors wish to thank Dr. E. Medei, from the University of Rio de Janeiro in Brasil, and Dr. A.A. Rodríguez-Menchaca, from the Universidad Autónoma de San Luis Potosí in México for the useful comments and critical review of the manuscript.

\section{Disclosure Statement}

The authors have nothing to disclose. 


\section{Cellular Physiology Cell Physiol Biochem 2016;40:1261-1273

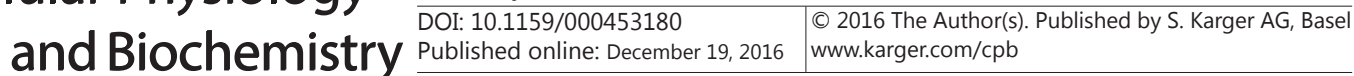 \\ Urrutia et al.: Cardiac $\mathrm{I}_{\mathrm{kr}}$ and $\alpha 1-\mathrm{AR}$}

\section{References}

1 Sanguinetti MC, Tristani-Firouzi M: hERG potassium channels and cardiac arrhythmia. Nature 2006;440:463-469.

2 Gordon E, Panaghie G, Deng L, Bee KJ, Roepke TK, Krogh-Madsen T, Christini DJ, Ostrer H, Basson CT, Chung W, Abbott GW: A KCNE2 mutation in a patient with cardiac arrhythmia induced by auditory stimuli and serum electrolyte imbalance. Cardiovasc Res 2008;77:98-106.

3 Priori S, Napolitano C, Paganini V, Cantu F, Schwartz P: Molecular biology of the long QT syndrome: impact on management. Pacing Clin Electrophysiol 1997;20:2052-2057.

4 Setién R, Alday A, Diaz-Asensio C, Urrutia J, Gallego M, Casis O: Mechanisms responsible for the trophic effect of beta-adrenoceptors on the I(to) current density in type 1 diabetic rat cardiomyocytes. Cell Physiol Biochem 2013;31:25-36.

5 Cui J, Melman Y, Palma E, Fishman GI, McDonald TV: Cyclic AMP regulates the HERG K+ potassium channel by dual pathways. Curr Biol 2000;10:671-674.

6 Kagan A, Melman YF, Krumerman A, McDonald TV: 14-3-3 amplifies and prolongs adrenergic stimulation of HERG K+ channel activity. EMBO J 2002;21:1889-1898.

7 Thomas D, Zhang W, Karle CA, Kathofer S, Schols W, Kubler W, Kiehn J: Deletion of protein kinase A phosphorylation sites in the HERG potassium channel inhibits activation shift by protein kinase A. J Biol Chem 1999;274:27457-27462.

8 Tutor AS, Delpón E, Caballero R, Gómez R, Núñez L, Vaquero M, Tamargo J, Mayor F Jr, Penela P: Association of 14-3-3 Proteins to ß1-Adrenergic Receptors Modulates Kv11.1 K+ Channel Activity in Recombinant Systems. Mol Biol Cell 2006;17:4666-4674.

9 Brelidze TI, Carlson AE, Zagotta WN: Absence of direct cyclic nucleotide modulation of mEAG1 and hERG1 channels revealed with fluorescence and electrophysiological methods. J Biol Chem 2009;284:2798927997.

10 Harmati G, Bányász T, Bárándi L, Szentandrássy N, Horváth B, Szabó G, Szentmiklósi JA, Szénási G, Nánási PP, Magyar J: Effects of $\beta$-adrenoceptor stimulation on delayed rectifier $\mathrm{K}(+)$ currents in canine ventricular cardiomyocytes. Br J Pharmacol 2011;162:890-896.

11 Jiang M, Dun W, Fan JS, Tseng G-NY: Use-Dependent 'Agonist' Effect of Azimilide on the HERG Channel. J Pharmacol Exp Ther 1999;291:1324-1336.

12 Bian J, Cui J, Mc Donald TV: HERG K+ channel activity is regulated by changes in phosphatidyl inositol 4, 5-bisphosphate. Circ Res 2001;89:1168-1176.

13 Bian JS, Kagan A, McDonald TV: Molecular analysis of PIP2 regulation of HERG and IKr. Am J Physiol Heart Circ Physiol 2004;287:H2154-H2163.

14 Kruse M, Hammond GR, Hille B: Regulation of voltage-gated potassium channels by PI(4,5)P2. J Gen Physiol 2012;140:189-205.

15 Kruse M, Hille B: The phosphoinositide sensitivity of the K(v) channel family. Channels (Austin) 2013;7:530-536.

16 Thomas D, Hammerling BC, Wimmer A-B, Wu K, Ficker E, Kuryshev YA, Scherer D, Kiehn J, Katus HA, Schoels W, Karle CA: Direct block of hERG potassium channels by the protein kinase C inhibitor bisindolylmaleimide I (GF109203X). Cardiovasc Res 2004;64:467-476.

17 Wang S, Xu DJ, Cai J, Huang Y, Zou JG, Cao KJ: Rapid component IKr of cardiac delayed rectifier potassium currents in guinea-pig is inhibited by $\alpha 1$-adrenoreceptor activation via protein kinase $A$ and protein kinase C-dependent pathways. Eur J Pharmacol 2009;608:1-6.

18 Wei Z, Thomas D, Karle DA, Kathöter S, Schenkel J, Kreye VA, Ficker E, Wible BA, Kiehn J: Protein Kinase A-mediated phosphorylation of HERG potassium channel in a human cell line. Chin Med J 2002;115:668676.

19 Thomas D, Wu K, Wimmer AB, Zitron E, Hammerling BC, Kathofer S, Lueck S, Bloehs R, Kreye VA, Kiehn J, Katus HA, Schoels W, Karle CA: Activation of cardiac human ether-a-go-go related gene potassium currents is regulated by $\alpha 1 \mathrm{~A}$-adrenoceptors. J Mol Med 2004;82:826-837.

20 Zhou Z, Gong Q, Ye B, Fan Z, Makielski JC, Robertson GA, January CT: Properties of HERG channels stably expressed in HEK 293 cells studied at physiological temperature. Biophys J 1998;74:230-241. 


\section{Cellular Physiology Cell Physiol Biochem 2016;40:1261-1273

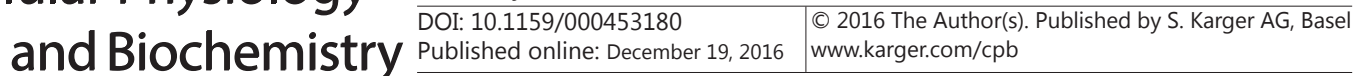 \\ Urrutia et al.: Cardiac $\mathrm{I}_{\mathrm{Kr}}$ and $\alpha 1-\mathrm{AR}$}

21 Sánchez-Chapula JA, Salinas-Stefanon E, Torres-Jácome J, Benavides-Haro DE, Navarro-Polanco RA: Blockade of currents by the antimalarial drug chloroquine in feline ventricular myocytes. J Pharmacol Exp Ther 2001;297:437-445.

22 Isenberg G, Klöckner U: Calcium tolerant ventricular myocytes prepared by preincubation in a "KB Medium". Pflügers Arch 1982;395:6-18.

23 Hamill OP, Marty A, Neher E, Sakmann B, Sigworth FJ: Improved patch-clamp techniques for highresolution current recording from cells and cell-free membrane patches. Pflügers Arch 1981;391:85-100.

24 McCrossan ZA, Abbott GW: The minK-related peptides. Neuropharmacology 2004;47:787-821.

25 Mironov SL: Metabotropic glutamate receptors activate dendritic calcium waves and TRPM channels which drive rhythmic respiratory patterns in mice. J Physiol 2008;586:2277-2291.

26 Smith KE, Browne L, Selwood DL, McAlpine D, Jagger DJ: Phosphoinositide Modulation of Heteromeric Kv1 Channels Adjusts Output of Spiral Ganglion Neurons from Hearing Mice. J Neurosci 2015;35:11221-11232.

27 Liu L, Heneghan JF, Mitra-Ganguli T, Roberts-Crowley ML, Rittenhouse AR : Role of PIP2 in regulating versus modulating Ca2+ channel activity. J Physiol 2007;583:1165-1166.

28 Roberts-Crowley ML, Mitra-Ganguli T, Liu L, Rittenhouse AR: Regulation of voltage-gated Ca2+ channels by lipids. Cell Calcium 2009;45:589-601.

29 Barros F, del Camino D, Pardo LA, Palomero T, Giraldez Channels T, De la Peña P: Demonstration of an inwardly rectifying $\mathrm{K}+$ current component modulated by thyrotropin-releasing hormone and caffeine in GH3 rat anterior pituitary cells. Pflügers Arch 1997;435:119-129.

30 Cayabyab FS, Schlichter LC: Regulation of an ERG K+ current by Src tyrosine kinase. J Biol Chem 2002;277:13673-13681.

31 Thomas D, Zhang W, Wu K, Wimmer AB, Gut B, Wendt-Nordahl G, Kathöfer S, Kreye VA, Katus HA, Schoels W, Kiehn J, Karle CA: Regulation of HERG potassium channel activation by protein kinase C independent of direct phosphorylation of the channel protein. Cardiovasc Res 2003;59:14-26.

32 Cockerill SL, Tobin AB, Torrecilla I, Willars GB, Standen NB, Mitcheson JS: Modulation of hERG potassium currents in HEK-293 cells by protein kinase C. Evidence for direct phosphorylation of pore forming subunits. J Physiol 2007;581:479-493.

33 Spector PS, Curran ME, Zou A, Keating MT, Sanguinetti MC: Fast inactivation causes rectification of the IKr channel. J Gen Physiol 1996;107:611-619.

34 Heath BM, Terrar DA: Protein kinase C enhances the rapidly activating delayed rectifier potassium current, $\mathrm{IKr}$, through a reduction in C-type inactivation in guinea-pig ventricular myocytes. J Physiol 2000;522:391402.

35 Gallego M, Setién R, Puebla L, Boyano-Adánez C, Arilla E, Casis O: alpha1-Adrenoceptors stimulate a G $\alpha$ S protein and reduce the transient outward $\mathrm{K}+$ current via a cAMP/PKA-mediated pathway in the rat heart. Am J Physiol Cell Physiol 2005;288:C577-C585.

36 Brown JH, Buxton ILO, Brunton LL: $\alpha 1$-adrenergic and muscarinic cholinergic stimulation of phosphoinositide hydrolysis in adult rat cardiomyocytes. Circ Res 1985;57:532-537.

37 Graham RM, Perez DM, Hwa J, Piascik MT: alpha 1-adrenergic receptors subtypes. Molecular structure, function, and signalling. Circ Res 1985;78:737-749.

38 Nishizuka Y: The molecular heterogeneity of protein kinase $\mathrm{C}$ and its implications for cellular regulation. Nature 1988;334:661-665.

39 Gallego M, Fernández D, Ahyayauch H, Casis E, Casis O: Reduced calmodulin expression accelerates transient outward potassium current inactivation in diabetic rat heart. Cell Physiol Biochem 2008;22:625634.

40 Zhang D-Y, Wang Y, Lau C-P, Tse H-F, Li G-R: Both EGFR kinase and Src-related tyrosine kinases regulate human ether-à-go-go-related gene potassium channels. Cell Signal 2008;20:1815-1821.

41 Barros F, Gomez-Varela D, Viloria CG, Palomero T, Giraldez T, De la Peña P: Modulation of human erg K+ channel gating by activation of a G protein-coupled receptor and protein kinase C. J Physiol 1998;511:333346.

42 Murray AJ: Pharmacological PKA inhibition: all may not be what it seems. Sci Signal 2008 DOI: 10.1126/ scisignal.122re4.

43 Kiehn J, Karle C, Thomas D, Yao X, Brachmann J, Kübler W: HERG potassium channel activation is shifted by phorbol esters via protein kinase A-dependent pathways. J Biol Chem 1998;273:25285-25291. 


\section{Cellular Physiology Cell Physiol Biochem 2016;40:1261-1273

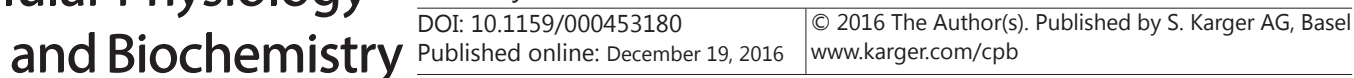 \\ Urrutia et al.: Cardiac $\mathrm{I}_{\mathrm{Kr}}$ and $\alpha 1-\mathrm{AR}$}

44 Baukrowitz T, Schulte U, Oliver D, Herlitze S, Krauter T, Tucker SJ, Ruppersberg JP, Fakler B: PIP2 and PIP as determinants for ATP inhibition of KATP channels. Science 1998;282:1141-1144.

45 Fan Z, Makielski JC: Anionic phospholipids activate ATPsensitive potassium channels. J Biol Chem 1997;272:5388-5395.

46 Liou HH, Zhou SS, Huang CL: Regulation of ROMK1 channel by protein kinase A via a phosphatidylinositol 4,5-bisphosphate-dependent mechanism. Proc Natl Acad Sci USA 1999;96:5820-5825.

47 Rohacs T, Chen J, Prestwich GD, Logothetis DE: Distinct specificities of inwardly rectifying K(+) channels for phosphoinositides. J Biol Chem 1999;274:36065-36072.

48 Shyng SL, Nichols CG: Membrane phospholipid control of nucleotide sensitivity of KATP channels. Science 1998;282:1138-1141.

49 Xie LH, Horie M, Takano M: Phospholipase C-linked receptors regulate the ATP-sensitive potassium channel by means of phosphatidylinositol 4,5-bisphosphate metabolism. Proc Natl Acad Sci USA 1999;96:1529215297.

50 Zhang H, He C, Yan X, Mirshahi T, Logothetis DE: Activation of inwardly rectifying K+ channels by distinct PtdIns (4,5)P2 interactions. Nat Cell Biol 1999;1:183-188.

51 Roberts-Crowley ML, Mitra-Ganguli T, Liu L, Rittenhouse AR: Regulation of voltage-gated Ca2+ channels by lipids. Cell Calcium 2009;45:589-601.

52 Berberián G, Forcato D, Beaugé L: Key role of a PtdIns-4,5P2 micro domains on ionic regulation of the mammalian heart Na+/Ca2+ exchanger. Cell Calcium 2009;45:546-553.

53 Matavel A, Lopes C MB: PKC activation and PIP2 depletion underlie biphasic regulation of IKs by Gqcoupled receptors. J Mol Cell Cardiol 2009;46:704-712.

54 Kubo T, Ding WG, Toyoda F, Fujii Y, Omatsu-Kanbe M, Matsuura H: Phosphatidylinositol4-phosphate 5-kinase prevents the decrease in the HERG potassium current induced by Gq protein-coupled receptor stimulation. J Pharmacol Sci 2015;127:127-134.

55 Huang CL, Feng S, Hilgemann DW: Direct activation of inward rectifier potassium channels by PIP2 and its stabilization by Gbetagamma. Nature 1998;391:803-806.

56 Wilde AA, Jongbloed RJ, Doevendans PA, Duren DR, Hauer RN, van Langen IM, van Tintelen JP, Smeets HJ, Meyer H, Geelen JL: Auditory stimuli as a trigger for arrhythmic events differentiate HERG-related (LQTS2) patients from KVLQT1- related patients (LQTS1). J Am Coll Cardiol 1999;33:327-332.

57 Kamarck T, Jennings JR: Biobehavioral factors in sudden cardiac death. Psychol Bull 1991;109:42-75.

58 Lown B: Sudden cardiac death: biobehavioural perspective. Circulation 1987;76:186-196.

59 Schwartz PJ, Priori SG, Spazzolini C, Moss AJ, Vincent GM, Napolitano C, Denjoy I, Guicheney P, Breithardt G, Keating MT, Towbin JA, Beggs AH, Brink P, Wilde AA, Toivonen L, Zareba W, Robinson JL, Timothy KW, Corfield V, Wattanasirichaigoon D, Corbett C, Haverkamp W, Schulze-Bahr E, Lehmann MH, Schwartz K, Coumel P, Bloise R: Genotype-phenotype correlation in the long-QT syndrome: gene-specific triggers for life-threatening arrhythmias. Circulation 2001;103:89-95.

60 Mow T, Frederiksen K, Thomsen MB: Assessment of anti-arrhythmic activity of antipsychotic drugs in an animal model: influence of non-cardiac $\alpha 1$-adrenergic receptors Eur J Pharmacol 2015;748:10-17. 